\section{Religious Culture and Medicinal Plants: An Anthropological Study}

Prakash Prasad Sapkota

\begin{abstract}
This study is based on primary data collection from the field from January 2011 to September 2013 to satisfy the query about the relation between religious culture and the medicinal plants. This study was carried out in Brahmin/ Chhetry dominated community of Baglung district of western development region of Nepal. The data were collected by using participant observation and interview. From this study it is found that, Brahmin/Chhetry use 48 plant species in their ritual, festivals and ceremony. Similarly they use 8 species in their religion. This entire plant species have important medicinal value. This plants species are necessary to complete their rituals, festivals, ceremony and religion but most of them have not knowledge about the medicinal value of these practicing plant species in their daily life. The answer of respondent is that, these plants are necessary for them because their ancestors use the plants but why they used the plants is unknown for them. This situation reflects that though the knowledge of medicinal value of the plants has vanished, it is still practiced on their religious culture.
\end{abstract}

Keywords: Religious culture, medicinal plants, Brahmin/Chhetry

\section{Introduction}

We all humans consider ourselves to be unique individuals with our own set of personal opinions, habits, preferences and quirks. Even then, we mostly share the feeling that it is wrong to eat while sleeping, to drink at laughing, to eat snake, dog meat, and the belief that bacteria, fungi and virus causes illness (Ember and Peregrine, 2002). We share many such feelings, beliefs and habits with most of the people living in the society and are also aware that other people have different feelings, beliefs and habits from ours. We, in the Nepali society, never think of the possibility of eating snake and dog meat but it is common in some societies abroad (ibid).

There are different views about culture. Culture refers to innumerable aspects of life. Most of the anthropologists define culture as the set of learned behavior, beliefs, attitudes, value and ideas that are characteristics of a particular society or population (Ember and Peregrine, 2002). From the beginning of the civilization, people have been learning from nature. Due to changing environment of the habitats as well as travels to new places, people often suffer from different diseases. To save and recover from them, people used plants and their parts by using trial and error methods (Binu 2011, Nagi et.al 2011, Berkes 2000). The plants which were useful to cure different diseases were collected and domesticated. Culturally, health and illness do not exist in social vacuum. The ideas and practices are influenced by the culture in which they lived. The knowledge of health and illness of people as well as researchers is stem from the culture in which they reside.

In many cultures of the world, it is believed that the body should be kept in balance between hot and cold or wet and dry. The idea of balance is not opposite; the body should be balanced for health. In Greek system of medicine there were four humors-blood, phlegm, yellow bile and black bile that must be kept in balance. These humors have both and cold, wet and dry properties. The Greek system of medicine was widely diffused in Europe and other part of the 
world. The Ayurvedic system was practiced in Indian continent where three humors- phlegm, bile and flatulence and hot and cold is also important. the Chinese medical system which dates back about 3500 years which was based on contrasting force of yin (exist in the underworld in the shape of house and tree) and yang (visible to living ghost) represent hot and cold respectively (Ember and Peregrine, 2002). In this way it was believed that the balance between the hot and cold of the body is the base of health. When people fainted with heat, bamboo-shoot soup was given because it was cold. For a month after child birth, women eat mostly meat, soup made of chicken, wine and sesame oil which are hot ingredient. It is accepted that hot things are generally oily, sticky which come from animals. The cold things tend to be soupy, watery and generally made from plants.

Most of the people of the world believed that supernatural power/beings can cause illness. George P. Murdock studied 139 societies cross-culturally and found that $56 \%$ societies those gods or spirits were the major cause of illness (Ember and Peregrine, 2002).In some societies; people simply think that their idea about health and illness are true. Browner found that certain plants are used to expel substance from the uterus that is, abortion or to induce menstrual flow. The other plants are used to retain things i.e. prevent miscarriage. Then the biomedical establishment has become increasingly aware about the value of studying the traditional medicinal remedies discovered or inverted by people around the world. Nina Etkin and Paul Ross studied the indigenous medicines of the Hausa of Nigeria and found that they use 600 plants and their possible medicine uses. More than 800 diseases and symptoms and more than 5000 prepared medicines. They eat many plants with antimalarial properties. The dietary consumption to these plants appears to greatest during the time of years when the risk of malarial infection is at its highest. The recent research has also discovered that foods and spices like garlic (Allium sativum), onion (Allium cepa), ginger (Zingiber officinale), cinnamon and pepper have antiviral and antibacterial properties. As said earlier, many native plants shown to be medically effective are related with their rituals and ceremonies.

Ethno-botany is a relatively new field of study in Nepal, as it is in many other developing countries. The people residing in rural areas have a close association with natural resources of their surroundings and possess hands-on knowledge about the various uses of plants that they need. This knowledge is scattered, communicated orally, and confined to certain main village members. This gap between the members of the society is as in different communities and different part of the country. Consequently, over the years, some of this traditional knowledge has been permanently lost or modified. Those plants which are relate with their cultural activities like rituals, ceremonies and festivals are protected by any means.

\section{The people}

The Brahmins is indo-Aryan origin and are capable of performing certain religious tasks, tradition of educator. They are Caucasian race with skin white, olive, and all shades of brown and sometimes dark brown. The hair form ranges from flat wavy to various degrees of curliness, usually hair wavy and the colour is of lighter shades, rarely dead black, texture is rarely coarse, usually medium to fine. Head form is variable; it ranges from dolichocephalic to brachycephalic. Nose is leptorrhine usually straight with medium thick tip, high nasal bridge. Face is narrow and oval with pointed chin, check bones are generally not prominent, the lips tend to be thin, chin is pronounced or medium in development, fore head is comparatively high. Eyes also have dark brownish to dark colour. They have slender and somewhat delicately built body and medium stature. They possess plentiful facial and body hair (Das 1999). on the basis of analysis of stature, cephalic and nasal index, H.K. Rakshit 1966, concludes that the Brahmin of India are heterogeneous and suggest incorporation of more than one physical type involving more than one migration of 
people. The physical variation from one human population to another is the result of one or more of the factors like as adaptation, acclimatization, and the influence of the social or cultural environment (Ember and Peregrine 2002).

Brahmins are the descent from the Rishis. During the sutra period between $1000 \mathrm{BC}$ to 200BC Brahmin divided in various shakshas on adaptation of different Vedas, at that time they flourished in Indian continent. They lead ahead on the core Vedic tradition and worship as the supreme lord Shiva. They refer to the supreme self. It refers to an individual belonging to Hindu priests, artists, teachers, technicians etc. the tribe/caste in which an individual is born. According to purusha sukta, a Rigveda humn, Brahmins were born from purusha's face. In ancient time they moved eastward along Xinxiang province of china, the western Tibet, the Himalayan foothills from Kashmir and Kumaun/Garwal and settle first in the Karnali river basin, then Gandaki and finally Koshi (Wikipedia, 2013). On the basis of analysis of stature, cephalic and nasal index the people of the study area are heterogeneous and have more than one physical type.

\section{Ritually used plants in Brahmin/Chhetri}

The core part of culture, the ritual is most important in different community of the world. In different community they have their own ritual and belief system to adopt with their environment. In Hindu mythology, the powder prepared from the rhizome to besar curcuma domestica is called as sarba aausadi and used in each and every activities like as curry, dal ritual and ceremonies etc. in the life cycle ritual of Brahmin/Chhetri many plant species are use with different meaning. In the naming ceremony (Newaran) they use leaves of Pipla (Ficus religiosa), bar ficus benghalensis, sami ficus benjamina, dubo cynadon dyctylon paiyun betula alnoides, kush desmostachya bipinnata, aanka calotropis gigantean, dumri ficus racemosa, tite pati
Artemisia indica and seed of jau arena sativa. In this ritual ceremony the father and mother prey with god and goddess for good health, fortune of newly born child. When the male child reaches ten, the parents manage bratabandha, that binds him culturally, physically as well as mentally within their environment. They collect and use of leaf of Pipal, Bar, Sami, dubo, paiyun, kush, dumri, tite pati, powder of basar, seed of rayo (Brassica juncea), tulsi(Oscimum sanctum) and Bambo (Bumbax cebia). The powder of basar is mixed with pure ghee and purified whole body after bathing with jau and til. At first batuk (boy starting this ceremony) wears janai made of kus at first, then made of pure thread. In marriage ceremony, they use the leaf of bar, pipal, kush, til, tulsi, basar, dubo, pati, banana and other colored flowers. In this ceremony from bridegroom should bring the three leaves of pipal, bar and sami with full of water in kalas and intermixed with bride kalas at first. In chaurasi puja leaf and branches of bar, papal, sami, mango, aanka,dumri, pakhari, dubo, jau, til, kush, bamboo, banana(Musa paradica), besar and other colored flowers are used. In chaurasi puja, they use the leaf of bar, pipal, sami, mango, banana, panyu, dumri, dubo jau, til and tulsi. They use dry wood of sami in the mondap to perform a sacrifice of jau, til, rice and ghee. This ceremony is celebrated on the occasion of observing of a thousand full moons. When a person reaches up to eighty four years, he/she can observe a thousand of full moon. In death ritual, they used dry plant of tulsi, kush, wood of sami, pest and wood of shreekhanda (Santaium album), jau, til, besar, zinger, bark of banana, dubo, bhringaraj(Eclipta prostrata), kapro(Ficus lacor) and white as well as yellow flowers the dry flower of tulsi, pati, mas (Vigna mungo) and bamboo. They believed that, the soul remains alive after the death of the body. The soul changes the body as we change the older cloths. The complete body is formed after ten days of ritually complete the 
procedure. They believed that, each day from the first of death, virangaraj is necessary. It plays vital role to form the complete body of soul. Similarly, in each ritual and ceremony kush is necessary which help to purify the materials as well as the people who are involved in ritual and ceremony. Then they can offer their gods and ancestors.

\section{Use of plants in ceremony/festivals}

In the Bramin community, they celebrate many ceremonies and festivals linked with the religion; which control and binds the members of the community. The ceremonies and festivals celebrate within a year are; the new year-the baishak first, they fellow almance of new year and observed bamgoda (left leg is effected on the basis of nachhetra) is the sign of evil. To save from the evil, the people celebrate santi-sowsti puja with nava graha(peace ceremony). In this ceremony, they prey the god Shiva, Vishnu, Ganesh, Durga and Nava Graha. In this peace ceremony, they used dubo, kush, til, jau, shrikhanda, leaf of rudrashkya, pati, basar. They give to eat til with honey for the affected people of bamgoda. In jestha-suckla panchami they celebrate diwali for good health and productivity of domestic animal. At that time, they use branch of pati, khirro (Holarrhena pubescens), jau, til and colored flowers. In jesti purnima, they celebrate kul puja. In this ritual, they use bamboo, pati, kush, jau til. The people become purified by bathing with jau and til as well as the verities of white and yellow flowers. The shrawan first, the maker sakranti in the evening they celebrate lutophalne. In this ceremony they use kurilo(Asparagus racemosus), siudi(Euphorbia royleana), aamilo (Citrus limon), seedlings of rice (Oriza sativa), saraddha (Olendra wallichii), bagh paile (Anemone rivulris), maker kanchi (Begonia picta), saldhoti, kauwa makai, bakhara kane(Inula cappa), indrany lahara (Trichosanthes wallichiana), siru (Imperata cycindrica), dubo, lutejhar (Galium hirtiflorum), kukurdaino
(Disporum cantoniense), kush, bet lauri (Costus specious), aakle bir (Clerodendrum indicum), magar kanchi (Begonia picta), rayo, jau til and kush. At the end of rice cultivation, at last Tuesday of shrawan they celebrate harelo. In this ceremony, they use khiroo, pati, jau til, kus, rayo, leaf of bhorlo(Bauhinia vahlii), kancho pat(Bitula utilis), husk of rice, mas, pati. They prey bhume, god of cultivated field, at the field. At the end of shrwan or first of bhadra full moon day they celebrate rishitarpani, popularly known as janai purnima. In this ceremony, they used leaf of bel, jau, kush, til, dubo and different flowers. In bhadra sukla panchami Brahmin female celebrate popular festival-Teej. In this festival, females share their experience and feeling of married life. It also play important role on binding force of relation between the family members with their married daughter. In this festival, they use 365 nodded branch of aakamaro(Achyranthes aspera), til, jau, kush, basar, gaura-parbata(Aeginetia indica) (representative of god Shiva and godess Parbati), pankopat (Piper longum). In ashoj, they celebrate shora saraddha, at that time they left to eat onion, lasun, venta, gahat, meat, millet like warmer food. They use besar, timilo (Ficus sp.), kush, til, jau, dubo, and flower of parijat (Nyctanthes arbortritis), and white as well as yellow flowers. At that time they remember and pray their ancestor. In Ashoj-Kartik, they celebrate Dasain festivals. At that time, they eat mostly warmer food like as meat, lasun, onion etc mostly but some of them never eat meat. In this festivals, they use zinger(Zingeber officinalii), sugarcan (Saccharum offecinarum), marigold(Tagetus patula), jamara(seedling of maize, wheat, rice, jau), pharshi, ghiraula(Luffa cylindrica), kuvindo (Benincasa hispida), bamboo, pati. In Kartik-Mangsir they celebrate Tihar, Bhaitaka festival. This festival strongly binds the relationship between brother and sister. At that time they use different flowers, jau, kush, til, dubo, oil of mustard, Bimiro (Citrus medica). In the morning of bhai tika, sister burst burning seed of okhar(Juglans regia) on the center of the base of main door. It is believed that, by this activity the brother life expectancy is increase. In this month, they also celebrate thuli aakadasi. In this festival they manage the married 
of tulsi with bamboo lilngo representative of god Vishnu. At that time they use kus, til, jau, fruit of bhogate (Maesa argentea) and flowers and eat sakharkhanda (Santaium album). Makar sakranti, the first day of magh, they eat tarul (Dioscorea deltoidea), vakhur (Dioscorea bulbifera), til, guda, ghee, pindalu (Remusatia pumila). In Falgun they celebrate Shiva Ratri. In this festival they prey god shiva by using the leaf and fruit of bel (Aegle marmelos) as a symbol of god Shiva. At that time they use bhang (Cannaibis sativa), dubo, jau, til and burning stem of sugarcane (Saccharum officinarum). In Chaitra they celebrate Cchaite Dasain. In this festival, they worship goddess Durga in the temple. At that time they use jau, til, kush and flowers.

Member of the people of Brahmin and Chhetri communities practice each their rites and rituals glorified as well as the name of God and identities (Sapkota, 2010). In different rituals and ceremony, people use different plants and their parts. The plants are used in purification of environment, materials and prayer people him/herself as kush, til and tulsi and feel happiness of their gods and goddesses. People offer certain plants like belpetra for god Shiva, Dubo for Ganesh. Similarly, they offer yellow flowers and flowers of parijat for their ancestor. People believed that happiness of god and their ancestors save their family members and community also from evil spirits on health, education and economy. This belief reflects that Brahmin and Chhetry have deep sign of religious value of god and their ancestor.

\section{Medicinal use of plants related with ritual, ceremony and festivals}

Most of the plants which are related with ritual, ceremony and festivals are important on medicinal point of view. These plants species are use to cure different diseases and illness of human being as well as their domestic animals.
Table1: Plants and different uses

\begin{tabular}{|c|c|c|c|c|c|}
\hline SN & $\begin{array}{l}\text { Local } \\
\text { name/ } \\
\text { famil } \\
\text { y }\end{array}$ & $\begin{array}{l}\text { Scientific } \\
\text { name }\end{array}$ & Habit & $\begin{array}{l}\text { Part } \\
\text { use }\end{array}$ & Use \\
\hline 1 & $\begin{array}{l}\text { Lasun } \\
\text { /Allia } \\
\text { ceae }\end{array}$ & $\begin{array}{l}\text { Allum } \\
\text { sativum }\end{array}$ & $\mathrm{hr}$ & rhz & $\begin{array}{l}\text { carminative, antiseptic, } \\
\text { antibacterial properties. }\end{array}$ \\
\hline 2 & $\begin{array}{l}\text { Payaj/ } \\
\text { Alliac } \\
\text { eae }\end{array}$ & $\begin{array}{l}\text { Allum } \\
\text { cepa }\end{array}$ & $\mathrm{hr}$ & peel & $\begin{array}{l}\text { Protenious, stimulant, } \\
\text { antibacterial property. }\end{array}$ \\
\hline 3 & $\begin{array}{l}\text { Aadu } \\
\text { wa/ } \\
\text { zingib } \\
\text { erace } \\
\text { ae }\end{array}$ & $\begin{array}{l}\text { Zingiber } \\
\text { officinale }\end{array}$ & $\mathrm{hr}$ & rhz & $\begin{array}{l}\text { carminative, astringent, } \\
\text { stimulant, diuretic \& } \\
\text { diaphoretic, loss of voice, } \\
\text { cough and colds. }\end{array}$ \\
\hline 4 & $\begin{array}{l}\text { Mula/ } \\
\text { crucif } \\
\text { erae }\end{array}$ & $\begin{array}{l}\text { Brassica } \\
\text { camprist } \\
\text { es }\end{array}$ & $\mathrm{hr}$ & seed & stomatic disorder. \\
\hline 5 & $\begin{array}{l}\text { Jau/gr } \\
\text { amine } \\
\text { ae }\end{array}$ & $\begin{array}{l}\text { Avena } \\
\text { sativa }\end{array}$ & $\mathrm{hr}$ & seed & energetic \\
\hline 6 & $\begin{array}{l}\text { Til/ } \\
\text { comp } \\
\text { posita } \\
\text { e }\end{array}$ & $\begin{array}{l}\text { Guizoita } \\
\text { abyssinic } \\
\text { a }\end{array}$ & $\mathrm{hr}$ & seed & $\begin{array}{l}\text { Oil use for burn, pest use } \\
\text { for scabies. }\end{array}$ \\
\hline
\end{tabular}


Dubo/ Cynodon pl
grami dyctylon

neae

tite Artimesi shr
pati / a indica
comp

osttae

9

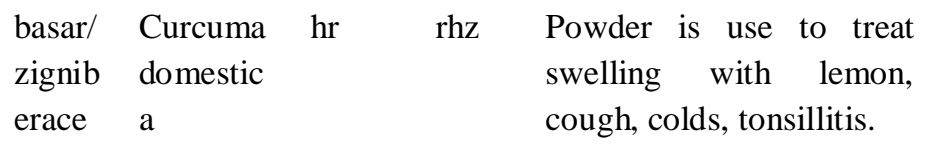

ae

aamp Mangifer tr

/ a indica

anaca

rdiace

ae
Relieve for indigestion, pest for cuts and wounds.

leaf, anthelmintic, pxpectorant, bran stomachic, antiseptic and ch emmenagogue. use in dyspepsia, hemorrhage and menorrhagia, abdominal pains, diarrhea, dysentery. Infusion of leaf for asthma, headaches, cuts and wounds. Used in to treat profuse menstruation, decoction of leaves is carminative, diuretic, expectorant, stimulant, abortifacient.

leaf, bark use for stomachic bark, disorder with mixing of latex Schima wallichii, root is in diuretic, bark for uaundice, rheumatism, pepticulcer, slender branches for toothache. leaf for cough, bronchial tube disease, juice for

dysentery, ask in burns, latex for gingivitis, gum and mustard oil for scabies, seed is vermifuge.

11

$\begin{array}{llll}\text { kera / } & \text { Musa shr } & \text { flow astringent } \\ \text { musa } & \text { paradisic } & & \text { ers }\end{array}$

ceae a

12 rayo Brassica hr /cruci juncea

ferae

13 Tulsi/ Ocimum

labiat sanctum/

ae tenuiflor um

14

$\begin{array}{lll}\text { aanka } & \text { Calotropi } & \text { shr } \\ / & \mathrm{s} & \\ \text { asclep } & \text { gigantea } & \\ \text { iadea } & \\ \text { ceae } & & \end{array}$

seed

oil is use in body ache.

leaf, stimulant, diaphoretic and bran expectorant. decoction or ch root for fever, gonorrhea, flow rheumatism, juice of leaf er, for ringworm, leaf for seed cough, colds and bronchial infection, seeds for demulcent, disorder of genitourinary system.

leaf, milky juice forspraind,

latex body pains, boils and pimples, on wonds or root affected area caused by leprosy, boils, pimples and other skin diseases. juice of root for diarrhea and dysentery. dried leaf are smoke through nose to relief sinusitis, powder 
flower in cough, colds, asthma.

15
Dumr Ficus tr leaf Leaf has religious value.

i/ racemosa

morac

eae

Shrik Santaium

handa album

santal

aceae

root, wood for cooling,

stem astringent, cardiac tonic, diuretic, fever, powder for gonorrhea, bile disorder, skin disease, oil for scabies, pest for head ache.

\begin{tabular}{|c|c|c|c|c|c|}
\hline 18 & simali & $\begin{array}{l}\text { Vitex } \\
\text { negundo }\end{array}$ & shr & leaf & $\begin{array}{l}\text { Use in gastric trouble, } \\
\text { cough, cold and for } \\
\text { sinusitis }\end{array}$ \\
\hline 19 & $\begin{array}{l}\text { Khirr } \\
\text { o/eup } \\
\text { horbi } \\
\text { aceae }\end{array}$ & $\begin{array}{l}\text { Sapium } \\
\text { insigne }\end{array}$ & $\operatorname{tr}$ & $\begin{array}{l}\text { bark, } \\
\text { fruit }\end{array}$ & $\begin{array}{l}\text { Root is use for cattle } \\
\text { stomach disorder, 2-3 } \\
\text { drops for indigestion. }\end{array}$ \\
\hline 20 & $\begin{array}{l}\text { kurilo } \\
\text { / } \\
\text { aspar } \\
\text { agace } \\
\text { ae }\end{array}$ & $\begin{array}{l}\text { Aspragus } \\
\text { racemosu } \\
\text { s }\end{array}$ & shr, cl & root & $\begin{array}{l}\text { as diuretic, demulcent, } \\
\text { aphrodisiac, } \\
\text { refrigerant, antiseptic, } \\
\text { alterative, } \\
\text { inducing, anti dysenteric, } \\
\text { antispasmodic, stomachic, }\end{array}$ \\
\hline
\end{tabular}
21 siudi/ Euphorbi tr eupho a
rbiace royleana
ae

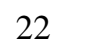

$$
\begin{array}{ll}
\text { aamil } & \text { Citrus } \\
\text { o/ } & \text { limon } \\
\text { rutace } &
\end{array}
$$$$
\text { ae }
$$

23 sarad

hya

24 bagh Anemon hr paile/ e good for bile, juice of the root is use for worms in hoofs or stomachs of animals. use for kidney and liver troubles, throat complaints, epilepsy, rheumatism, dyspepsia, gonorrhea. leaves are fried in clarified butter and give to relieve night blindness, fruits for pimples.

pith, boiled pith is useful for leaf, stomach disorders and milk gastric troubles. paste of $\mathrm{y} \quad$ leaf is use in cuts and latex wounds, juice of leaf for fever, latex in muscular swellings, 5-7 drops of latex with a cup of water is useful in cough and asthma.

leaf leaf is used to open voice less on throat. 


\begin{tabular}{|c|c|c|c|c|c|}
\hline & $\begin{array}{l}\text { ranun } \\
\text { culac } \\
\text { eae }\end{array}$ & rivularis & & , leaf & $\begin{array}{l}\text { use in cuts and wonds, } \\
\text { leaf juice with water is } \\
\text { use in sinusitis. }\end{array}$ \\
\hline 25 & $\begin{array}{l}\text { sal } \\
\text { dhoti }\end{array}$ & & $\mathrm{hr}$ & plant & $\begin{array}{l}\text { Mix with other plants to } \\
\text { prepare drugs. }\end{array}$ \\
\hline 26 & $\begin{array}{l}\text { kauw } \\
\text { a } \\
\text { makai }\end{array}$ & & $\mathrm{hr}$ & fruit & $\begin{array}{l}\text { Mix with other plants to } \\
\text { prepare drugs. }\end{array}$ \\
\hline 27 & $\begin{array}{l}\text { bakha } \\
\text { ra } \\
\text { kane/ }\end{array}$ & $\begin{array}{l}\text { Inula } \\
\text { cappa }\end{array}$ & $\mathrm{hr}$ & $\begin{array}{l}\text { Root } \\
\text { fruit }\end{array}$ & $\begin{array}{l}\text { Root juice for peptic } \\
\text { ulcer, gastric trouble. }\end{array}$ \\
\hline & $\begin{array}{l}\text { comp } \\
\text { ositae }\end{array}$ & & & & \\
\hline 28 & $\begin{array}{l}\text { indra } \\
\text { ni } \\
\text { lahara } \\
\text { / } \\
\text { cucur } \\
\text { bitace } \\
\text { ae }\end{array}$ & $\begin{array}{l}\text { Trichosa } \\
\text { nthes } \\
\text { wallichia } \\
\text { na }\end{array}$ & hr,cl & & $\begin{array}{l}\text { Mix with other plants to } \\
\text { prepare drugs. }\end{array}$ \\
\hline 29 & $\begin{array}{l}\text { siru/ } \\
\text { grami } \\
\text { neae }\end{array}$ & $\begin{array}{l}\text { Imperata } \\
\text { cylindric } \\
\text { al }\end{array}$ & $\mathrm{hr}$ & root & $\begin{array}{l}\text { root boiled with water use } \\
\text { as anthelmintic, decoction } \\
\text { of root use for diarrhea } \\
\text { and dysentery, gastric, } \\
\text { astringent, diuretic and } \\
\text { tonic. Juice of root is use } \\
\text { for asthma jaundice } \\
\text { dropsy and nosebleed. }\end{array}$ \\
\hline
\end{tabular}

$\begin{array}{ll}\text { aakle } & \text { Cleroden shr } \\ \text { bir / drum } & \\ \text { libiata indicum } & \end{array}$

libiata indicum

e

33 lute Galium hr jhar / hirtifloru rubiac $m$ eae
Paste of inflorescence is use in cuts and wounds. $\begin{array}{ll}\text { daino } & \mathrm{m} \\ / & \text { cantonie } \\ \text { conva } & \text { nse }\end{array}$ llariac eae

31 bet Costus lauri / specious Zingi berac eae hhr, cl root juice of root is use in

fever.

\begin{abstract}
plant plant has antipyretic and diuretic properties. Juice root of root is useful for fever, skin disease, worms, dyspepsia, indigestion, cough and colds. Juice of stem in diarrhea and dysentery, urinary trouble.
\end{abstract}

root, juice of root use in cough bark, and colds, asthma, bark leaf juice is use for malnutrition, juice of leaf is applied to eruptions on the feet.

plant pest of the plant is use in treating scabies. 


\begin{tabular}{|c|c|c|c|c|c|}
\hline 34 & $\begin{array}{l}\text { bimer } \\
\text { o / } \\
\text { rutace } \\
\text { ae }\end{array}$ & $\begin{array}{l}\text { Citrus } \\
\text { medica }\end{array}$ & $\operatorname{tr}$ & fruit & $\begin{array}{l}\text { use in dysentery, also } \\
\text { help in digestion. }\end{array}$ \\
\hline 35 & $\begin{array}{l}\text { viring } \\
\text { araj/ } \\
\text { comp } \\
\text { ostiae }\end{array}$ & $\begin{array}{l}\text { Eclipta } \\
\text { prostrate }\end{array}$ & $\mathrm{hr}$ & $\begin{array}{l}\text { plant } \\
\text { root }\end{array}$ & $\begin{array}{l}\text { paste of plant is use for } \\
\text { wound and skin diseases, } \\
\text { blood purification in } \\
\text { whole night cup of a } \\
\text { water, juice of plant is use } \\
\text { for cuts, tattooing, } \\
\text { burning starting during } \\
\text { urination, fever. Root } \\
\text { juice is use in cuts, } \\
\text { wounds and pimples, } \\
\text { fever, liver tonic. Paste of } \\
\text { seed is use in headaches. }\end{array}$ \\
\hline 36 & $\begin{array}{l}\text { kapro } \\
\text { / } \\
\text { morac } \\
\text { eae }\end{array}$ & $\begin{array}{l}\text { Ficus } \\
\text { lacor }\end{array}$ & $\operatorname{tr}$ & latex & $\begin{array}{l}\text { milky latex is applied to } \\
\text { boils. }\end{array}$ \\
\hline 37 & $\begin{array}{l}\text { Bimir } \\
\text { o/ruta } \\
\text { ceae }\end{array}$ & $\begin{array}{l}\text { Cytrus } \\
\text { medica }\end{array}$ & $\operatorname{tr}$ & $\begin{array}{l}\text { Leaf } \\
\text { root }\end{array}$ & $\begin{array}{l}\text { Use in dysentery and } \\
\text { helps in digestion }\end{array}$ \\
\hline 38 & $\begin{array}{l}\text { bharl } \\
\text { o/ } \\
\text { legum } \\
\text { inace } \\
\text { ae }\end{array}$ & $\begin{array}{l}\text { Bauhinia } \\
\text { vahlii }\end{array}$ & shr, cl & $\begin{array}{l}\text { root, } \\
\text { leaf, } \\
\text { bark }\end{array}$ & $\begin{array}{l}\text { juice of the is use in to } \\
\text { treat amebic dysentery. } \\
\text { bark boiled with water } \\
\text { and the paste is use in } \\
\text { boils, decoction of leaf is } \\
\text { use in diarrea and }\end{array}$ \\
\hline
\end{tabular}

\begin{tabular}{|c|c|c|c|c|c|}
\hline 39 & $\begin{array}{l}\text { magar } \\
\text { kanch } \\
\text { e/ } \\
\text { begon } \\
\text { iaceae }\end{array}$ & $\begin{array}{l}\text { Begonia } \\
\text { picta }\end{array}$ & $\mathrm{hr}$ & $\begin{array}{l}\text { plant } \\
\text {, leaf }\end{array}$ & $\begin{array}{l}\text { juice of plant is use in } \\
\text { headaches. leaf are use in } \\
\text { sore nipples. Juice of root } \\
\text { is use in conjunctivitis. }\end{array}$ \\
\hline 40 & $\begin{array}{l}\text { paiyu } \\
\mathrm{n} / \\
\text { betula } \\
\text { ceae }\end{array}$ & $\begin{array}{l}\text { Betula } \\
\text { alnoides }\end{array}$ & $\mathrm{tr}$ & bark & $\begin{array}{l}\text { bark is boiled with water } \\
\text { and use for dislocated } \\
\text { bone. }\end{array}$ \\
\hline 41 & $\begin{array}{l}\text { bhojp } \\
\text { atra }\end{array}$ & $\begin{array}{l}\text { Bitula } \\
\text { utilis }\end{array}$ & $\operatorname{tr}$ & $\begin{array}{l}\text { bark, } \\
\text { resin }\end{array}$ & $\begin{array}{l}\text { bark has carminative and } \\
\text { antiseptic properties and } \\
\text { its infusion is use in } \\
\text { hysteria, boiled with } \\
\text { water is use in jaundice. } \\
\text { paste of resin is use in } \\
\text { boils, contraceptive } \\
\text { purposes. }\end{array}$ \\
\hline 42 & $\begin{array}{l}\text { gaura } \\
\text { parbat } \\
\text { a/ } \\
\text { oroba } \\
\text { nchac } \\
\text { eae }\end{array}$ & $\begin{array}{l}\text { Aegineti } \\
\text { a indica }\end{array}$ & $\mathrm{hr}$ & root & $\begin{array}{l}\text { juice of the root is taken } \\
\text { to treat fever. }\end{array}$ \\
\hline 43 & $\begin{array}{l}\text { aaka } \\
\text { maro/ } \\
\text { amara } \\
\text { nthac }\end{array}$ & $\begin{array}{l}\text { Achyrant } \\
\text { hes } \\
\text { aspera }\end{array}$ & hr & $\begin{array}{l}\text { root, } \\
\text { plant }\end{array}$ & $\begin{array}{l}\text { infusion of root is } \\
\text { astringent, and paste is } \\
\text { use in stomach troubles, } \\
\text { cholera, skin diseased, } \\
\text { rheumatic problems. juice }\end{array}$ \\
\hline
\end{tabular}


eae

$\begin{array}{lllll}\begin{array}{l}\text { sarad } \\ \text { hya/ }\end{array} & \begin{array}{l}\text { Olendra } \\ \text { wallichii }\end{array} & \begin{array}{l}\text { epi/ } \\ \text { fern }\end{array} & \begin{array}{l}\text { rhizo } \\ \text { me }\end{array} & \begin{array}{l}\text { paste of rhizome is use to } \\ \text { treat } \\ \text { dislocation of bones. }\end{array}\end{array}$

terida

$\begin{array}{lll}\text { parija } & \text { Nyctanth tr } \\ \text { t/ } & \text { es } \\ \text { oleac } & \text { arbortriti }\end{array}$

eae $s$ is use to treat postnatal pain and to accelerate expulsion of the placenta, indigestion, colic and food poisoning. Powdered root is giben for diarrhea and dysentery. the plant is digestive, diuretic, putative, laxative, stomachic, and astringent. Juice of the plant is use for boils, diarrhea, dysentery, hemorrhoids, rheumatic pains, itches and skin eruptions. Pest of leaf is use forhusteria, nervous disorder, insect bite and snake bite.

dislocation of bones.

$$
\begin{aligned}
& \text { bark, paste of bark is use to } \\
& \text { leaf treat dislocated bones, } \\
& \text { juice of bark is use for } \\
& \text { snake bites. leaf boil with } \\
& \text { water use for fever, } \\
& \text { rheumatism, decoction } \\
& \text { of leaf is good for }
\end{aligned}
$$

obstinate sciatica.

46 bhang Cannabis shr leaf, Juice is use in diarrhea o/ sativa seed and dysentery, pest of leaf canna is use in cuts and wounds. bacea Seed is given as an e anthelmintic.

$\begin{array}{ll}\text { bhoga } & \text { Maesa } \\ \text { te } & \text { argentea }\end{array}$

leaf leaves are use in to poison fish.

48 shrikh Santaium tr anda/ album root, wood is cooling, santal stem astringent bitter sedative, ardiac tonic and diuretic, fever, powder of wood is use in gonorrhoea, fevers and bilious disorders.

Note: hr-herb, shr-shrub, tr-tree, cl-climber, epi-epiphyte,rhz-rhizome.

\section{Relation between religion and medicinal plants:}

All the communities possess belief which can be grouped under the term religion. The knowledge gap between thinking and practice of the people leads towards the supernatural power, gods, sprites, ghosts or demons. The supernatural power believed to be not human or non subject and varies from society to society. In many culture religious is embedded in other aspects to everyday life. According to Tylor, religion originated in people's speculation about dreams, trances and death (ref. by Ember and Ember 2002). A religion is a set of spiritual beliefs about two key aspects of life: concern with the ultimate meaning of human existence; and identification with a supernatural power beyond the limits of the human and natural worlds. The many different religions have different beliefs about these two aspects of 
life. In any religion some things are common as ceremonial and ritual acts which focus on sacred objects and symbols; communication, notably through prayer, with the supernatural power. In particular religious feelings, such as a sense of mystery, awe, adoration and reverence, which tend to be aroused in the presence of sacred objects or symbols, and during ceremonies and rituals associated with the supernatural power (UNISCO 2010). The theories of religion agree on the beliefs or rituals, religion may satisfy psychological needs common to all people. But social scientists believe that religion springs from society and serves social, rather than psychological need. Many anthropologists follow the view that religions are adaptive because they reduce the anxieties and uncertainties that afflict all peoples. In different societies on the basis of environment they keep the relation between the important plants with their religion. Some plants have great religious significance. People worship them as icons of gods and goddesses to they are grown or protected with special care (Manandhar2002). Sacred plants are mentioned in ancient Hindu literature, including the Vedas, the Purans, the Ramayan and Mahabharat. In Hindu religion of Brahmin and Chhetry, they relate most of the useful plants on their religion, festivals and ceremonies. Some of the important religious plants are:

- Belpatra (Aegle marmelos)- symbol of god shiva.

- Bar (Ficus benghalensis) - symbol of Vishnu, purus.

- Pipal (Ficus religiosa) - symbol of Vishnu, prakarti.

- Sami (Ficus benjamina) - symbol of shiva, Vishnu.

- Tulsi (Oscimum tenuiflorum )- symbol of Vishnu.

- Kush (Desmostachya bipinnata) -symbol f Vishnu.

- Gaura parbata (Aeginetia indica) - symbol of shiva and parbati.

- Aamala (Phyllanthus embilica) - symbol of lakshmi.

Medicinal value to these religious plant species is as follows.

Belpatra (Aegle marmelos)-The plants comes under the family rutaceae. It is deciduous,throny tree about $15 \mathrm{~m}$ height. Juice of the root is use for fever, juice of bark and mustard seeds are use to treat diarrhea and dysentery, leaves are astringent, digestive, febrifuge and laxative. Unripe fruit is astringent, digestive and stomachic.

Bar (Ficus benghalensis) - Family moraceae, evergreen tree about $35 \mathrm{~m}$ height. An infusion of bark is tonic in the treatment of diabetes, young leaves are use as a poultice, latex for rheumatism, bleeding and swelling of the gums, and mixed with sugar to treat dysentery.

Pipal (Ficus religiosa) - Family moraceae, deciduous tree about 35m height .Bark is astringent and use to treat gonorrhea, bark for scabies, juice of bark is used for diarrhea and dysentery, toothaches and aching gums. Leaf boiled with water and filter is used to treat earaches. Pest of young leaf and shoot is used for skin disease. Fruits are laxative.

Sami (Ficus benjamina) - Family moracear, evergreen tree. The milky latex is use in boils.

Tulsi (Oscimum tenuiflorum)- Family labiatae,shrup about $80 \mathrm{~cm}$ high. The whole pl ant is stimulant, diaphoretic and expectorant. Decoction of root is given for fever, to treat gonorrhea, rheumatism and paralysis. Juice of leaves is applied to treat ringworm gastric trouble, eareches, cough, colds, and bronchial infection, seed soaked in water about $10 \mathrm{hrs}$ is used to treat the disorders of the genitourinary system.

Kush (Desmostachya bipinnata)- Family gramineae, perennial grass about $2 \mathrm{~m}$ high. Juice of the root is given in cases of indigestion, paste of the root is applied to treat dental caries, culms are used in diuretic and dysentery.

Gaura parbata (Aeginetia indica) - Family orobanchaceae,leafless herb about $20 \mathrm{~cm}$ high. Juice of the root is taken to treat fever.

aamala pyylanthus emblica- Family euphorbiaceae, tree about $15 \mathrm{~m}$ heigh. seeds are rich in vitamin c. It is strong antioxidant and tonic of hair, diuretic, laxative, cardio protective. useful in hemorrhage, body of briole discharge of blood from uterus. it is also useful for remove of wrinkle and sun burn. 
The religious and cultural beliefs of the people of any community have also contributed to the protection of most important plants and their habitat. The people are varying conscious of the need to protect plants at religious places also. This behavior of the people helps to adopt with their environment.

\section{Adhesive force between religion and medicinal plants}

People always struggle for the adoption with their environment. Due to the changing environment, food, daily activities the balance between hotness and coldness of the body is also changes and people suffer from many diseases and illness. To save from the diseases and cure the illness he/she should change himself according to the environment. To cure the illness, people should be use available medicine. Most of the rural people of Nepal develop the adhesive force between religion and medicinal plants. Why they do so? is an important query. Medicinal plants are easily available with their environment, cheep, has not side effect and transfer the knowledge from their ancestors, which was already used and proof from trial and error method. On the other hand modern medicines are more costly, has side effect not easily available. Most of the modern drugs are mainly antibiotics, which do not eradicate disease but only suppressed. When the condition of the body is slightly change the disease reappear. It is believed that except surgical case, the power of medicinal plants is higher though it takes some times to cure the disease completely. So, in develop countries like as American $42 \%$, Japan $60-70 \%$, European more than $40 \%$, prefer medicinal plants to cure their diseases and illness. In India, more than $60 \%$ use medicinal plants and in our country more than $60 \%$ use medicinal plants at first to cure different diseases and illness (WHO 2002).

All the people of the world believe their own religions according to their knowledge, belief system, taboo etc. The religion is a kind of key which can bind the people strongly though the entire individual are different to each other on their interest, thinking, vision, behavior, aim, perception etc. It can control the individual to cross the line which is developed to adjust easily within their environment. The knowledgeable people of the past understand the power of the religion. Then they develop the adhesive force between religion and medicinal plants to protect medicinal properties of plant and transfer the knowledge continuously for their descendents to adjust easily with their changing environment.

\section{Medicinal plants at present}

In Brahmin/Chhetry community, they use many plants in their ritual, ceremony and festivals. The different plants species which are necessary to complete certain activities of a festival are collect by them. They collect the plant species from heir surrounding and celebrate it. When asked with respondents why use this plant species? they only answered that it is necessary to complete in this ceremony. Nearly $99 \%$ of the people are unknown the use of this important medicinal value of the plant but use in ritual, festivals and ceremony. Only one to two person of a community have the knowledge of medicinal value which they have in practice. They have also little knowledge of medicinal plant and in practice. Most of the people are attracted on modern medicine, so we left to use and forgot continuously some respondent said. They add, when modern medicine is not effective then some people search medicinal plants.

Young people have not chance to observe the use of medicinal plants and their effects on the one hand, the knowledge is not transferred to them properly on the other. They are motivated towards theoretical education and the daily work. So they have not any knowledge of medicinal plants and hence no interested about it. The young take each activities of culture in surface and neglected 
continuously. They think, their own culture is rood and always search new one in the name of modernization and suffer a lot. In this

situation, people are compelled to use modern medicine though it is so costly and has side effect. On the other hand most useful medicinal plants are damage naturally itself. The professional people who have the knowledge of medicinal use of the plants is harvested rampantly and lost rapidly i.e. satuwa (Paris polyphylla), yarchagumba (Cordyceps sinensis) etc. This activities of the people led towards the knowledge on medicinal plant is rusted and lost forever on one hand and having knowledge on some remains in indistinct condition. It makes people dependent day by day in the name of modernization and suffers from new diseases and illness one after the other.

\section{Conclusion}

From the above research it is found that, the Brahmin/Chhetry people use 48 medicinal plant species in their ritual, ceremony and festivals. Similarly 8 important medicinal plant species are unavoidable components in their religious ceremonies. hy? they only relate medicinal plants in their religion, ceremony, ritual and festivals and not other is the major question. Plants have always been a central part of the life and culture of the Nepalese people (Manandhar 2002), and all aspects of the Nepalese folk life and beliefs are related to flora (Shrestha et al.2004). Certainly they did not adhere to these medicinal plants unknowingly. They developed different procedure to protect the knowledge of important medicinal plants which are interlinked directly with their life activities. Late, they would be developed into different cultural activities like as religion, ceremony, ritual and festivals on the basis of their importance. The knowledge is gathered by the people on trial and error method and use to cure different diseases and illness from which they suffered. The answer of why people adhere medicinal plants in their religion is that, man depends on plants for food, medicine and shelter. Health is most important and

all the plants have not equal value on food and medicinal point of view. Foods crops are cultivated and familiar for all but medicinally important plants are wild in nature and if it lost a time, it will be lost forever. So for the tactful management and continuously transfer the knowledge for their coming generation ancestors integrate the medicinally valuable plants with their ritual, ceremony and festivals which helps to transfer the knowledge for all the members of community from youths to children, if not we have not the answer of the above question.

From this research study it can be concluded that, the Brahmin/Chhetry community's religion, rituals, ceremony and festivals are complete only by using useful and important medicinal plants. It shows that medicinal plants and people have strong adhesive force. The strength of force is depends up on the importance of the plants to adopt within their environment. The people are only controlled and motivated internally by their own religion, ceremony and festivals by which they become as human being socially from the beginning. The image which attach on mind of a children is not easily erased. The sign of image is seen in each activity of people in their life span. So the force is created by knowledgeable people to protect the local name of the medicinal plants and its importance to remain healthy and alive for themselves as well as their coming generation. At present 56 plants species are necessary to complete their rituals, festivals, ceremony and religion but most of them have not knowledge about the medicinal value of these plant species in their daily life. The answer of respondent is that, these plants are necessary for them because their ancestors used them but why they used the plants is unknown for them. This situation reflects that the knowledge of medicinal value of the plants has nearly vanished but it still adheres to 
their religious culture which in a sense protects the local name of these plant species.

\section{Reference}

Berkes f., colding j. and c. folk (2000). Rediscovery if traditional ecological knowledge as adaptive management. Ecological applications 10 (5).

Binu S. (2011). Medicinal plants used for treating body pain by the tribals in pathanamthitta district, kerala, India. Trobical

Botanic garden and research, Department of botany, Andhra university. Indian journal of traditional knowledge, national institute of science communication and information resources, new Delhi, India.

Das B.M.( 1999). Outline of Physical Anthropology. Kitab Mahal, Allahabad, India.

Ember C.R. and Peregrine P.N. (2002). Anthropology. Pearson Education Asia, Replica Press India.

Manandhar, N.P.(2002). Plants and People of Nepal. Timber press, Inc Portland, oregan USA

Negi Vikram S., Maikhuri RK and Vashistha DP.(2011). traditional healthcare practices among the villages of Rawain velley, Uttarkashi, Uttar khanda, india. GB plant institute of Himalayan environment and development, India. Indian journal of traditional knowledge, national institute of science communication and information resources, new Delhi, India.

Sapkota P.P.(2010), the Ritual use of jhakro in Magar Community. Dhaulagiri Journal of Sociology and Anthropology, Vol 4. Dept.of Sociology/Anthropology Dhaulagiri Multiple Campus Baglung, Nepal.

Shrestha K.K. Rajbhandary, S. Tiwari N.N, Poudel R.C and Uprety Y.(2004). Ethnobotany of Nepal;Review ans perspectives. Kathmandu, Nepal; WWF Nepal Program.
WHO (2002), WHO Traditional medicine Strategy 2002-2005.World Health Organization.

Wikipedia (2013). http;www. Wikipedia.com. 